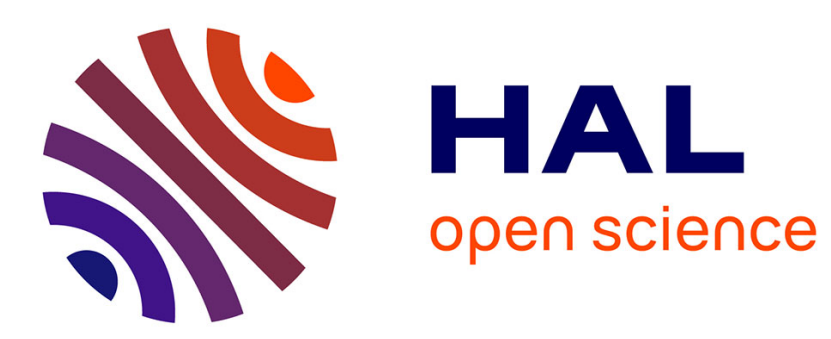

\title{
Linguistic expressions of Goal, Source and Place in Polynesian languages
}

\author{
Claire Moyse-Faurie
}

\section{To cite this version:}

Claire Moyse-Faurie. Linguistic expressions of Goal, Source and Place in Polynesian languages. Studies in Language, In press, 10.1075/sl.00017.moy . hal-03094671

\section{HAL Id: hal-03094671 \\ https://hal.science/hal-03094671}

Submitted on 20 Jan 2021

HAL is a multi-disciplinary open access archive for the deposit and dissemination of scientific research documents, whether they are published or not. The documents may come from teaching and research institutions in France or abroad, or from public or private research centers.
L'archive ouverte pluridisciplinaire HAL, est destinée au dépôt et à la diffusion de documents scientifiques de niveau recherche, publiés ou non, émanant des établissements d'enseignement et de recherche français ou étrangers, des laboratoires publics ou privés. 
Linguistic expressions of Goal, Source and Place in Polynesian languages

Claire Moyse-Faurie

UMR 7107 Lacito-CNRS

claire.moyse@cnrs.fr

\begin{abstract}
In Polynesian languages, as in many other Oceanic languages, the linguistic expression of Source and Goal is mainly express by (i) demonstratives and directional modifiers, which combine deictic and spatial information (toward speaker, addressee or third person, upwards, downwards, transverse axe), (ii) locative static and dynamic prepositions (which may combine with body-part terms to introduce local and landmark nouns, or place names, and (iii) posture and motion verbs. We examine the occurrences of the Source and Goal prepositions on the one hand, and the directional modifiers on the other, taking into account their compatibilities, the spatial coding they convey, the position of the participants, and the verb meaning. In Polynesian languages, Goal and Source are of similar complexity, though in different ways, and a variety of resources can express fine-grained distinctions for Source vs. Goal depending on the position of the figure.
\end{abstract}

Keywords: Polynesian languages, East Uvean, East Futunan, demonstratives, directional adverbs, locative prepositions, position and motion verbs 


\section{Introduction}

This article is concerned with the linguistic expression of Source and Goal in some Polynesian languages, mainly East Uvean/Faka'uvea (c. 20000 speakers in Wallis and New Caledonia) and East Futunan/Fakafutuna (c. 10000 speakers in Futuna and New Caledonia), both belonging to the Nuclear Polynesian subgroup of the Polynesian family. My data comes from traditional oral texts and conversations, and from descriptions elicited with the Trajectoire stimuli (Ishibashi et al, 2006)ํ. Data from other Polynesian languages comes from descriptive grammars. In these Polynesian languages, as in many other Oceanic languages, spatial reference is mainly expressed by (i) demonstratives/deictics and presentatives, (ii) directional adverbs which combine deictic and spatial information (toward speaker, addressee or third person, upwards, downwards, transverse axis), (iii) locative prepositions (static/essive, ablative/ventive/dynamic centripetal and allative/dynamic centrifugal) which combine with object-part terms or with verbs to introduce local and landmark nouns, place names, etc., (iv) position and motion verbs. I will first present the inventory of source, place and goal linguistic expressions, mainly conveyed by locative prepositions and directional adverbs, in combination with position, gesture and motion verbs (sections $1 \& 2$ ). I will then examine the interactions between the two types of expressions - prepositions and directionals - and try to determine their respective functions in the encoding of Source and Goal (section 3). Each section will end with considerations concerning the possible existence of asymmetry between the expressions of Source and Goal. Since in some cases the essive preposition can express the Source, I will also take into consideration the expression of Place.

Contrasting with the situation in several other Austronesian languages, I found no cases of zero-marking of spatial relations, as defined in Stolz et al. (2014). There are,

\footnotetext{
${ }^{1}$ I am very grateful to Anetta Kopecka, Marine Vuillermet, Andrew Pawley and the anonymous evaluators for inspiring comments on an earlier version of the article.
} 
however, marginal instances of spatial relations expressed through noun incorporation or adverbial strategies, which will be presented in section 4 , since they also present some cases of asymmetry.

The conclusion will summarise how Source, Place and Goal are expressed in these Polynesian languages, whether their encodings differ in complexity or not, and whether the asymmetry between Goal and Source reflects what is found cross-linguistically.

\section{Locative prepositions}

Creissels (2006:19) identifies five logical different patterns for encoding the distinction between Place, Source and Goal of motion:

- Pattern 1 associates without any ambiguity each of the three meanings with a specific marker (an adposition or an affix).

- Pattern 2 comprises three different cases of conflation between the three meanings: (a) ablative vs. essive-allative, (b) allative vs. essive-ablative and (c) essive vs. allative-ablative. - Pattern 3 makes no grammatical distinction in the marking of the three meanings.

Pattern 1 and Pattern 2(a) are common in European languages, Pattern 2(b), though rare, is attested in languages spoken in North East Africa (Creissels 2006:22), and in Samoan (see below). Pattern 2(c) has not been identified so far. A case of Pattern 3 has been thoroughly described in Wan, a South Eastern Mande language (Nikitina 2009).

At least two Polynesian languages, East Futunan and Tuvaluan, mix two patterns: Pattern 2(b) allative vs. essive-ablative, along with Pattern 1 in which each of the three meanings - essive, ablative and allative - is primarily associated with one preposition. Indeed, in most Polynesian languages, three locative prepositions are attested, all of them being reflexes of Proto Polynesian (PPn) etyma (cf. Pollex Online, Greenhill S.J. \& Clark R. 2011): 
i. $\quad$ PPn $* \mathrm{i}<$ Proto Oceanic $(\mathrm{POc}) * \mathrm{qi}$ 'a preposed locational particle, at or from a position'. In the languages listed in Pollex, reflexes of $*_{\mathrm{i}}$ are described as spatiotemporal prepositions; 'at, in, on'.

ii. $\quad P P n * k i$ 'preposition indicating motion towards, to; direction towards a goal including physical movement but extending to the arguments of perception, communication and cognition'.

iii. PPn *mai 'from, since'2. The only logical source for PPn *mai 'from' is the POc verb *mai 'come' and the POc adverbial directional *mai 'towards speaker'. As some Polynesian languages have mai as the reflex, that form must be attributed to PPn (A. Pawley, pers. com.).

According to Mosel and Hovdhaugen (1992), one variety of Samoan has only two prepositions, and thus constitutes a case of conflation:

i. the dynamic centrifugal preposition PPn *ki is reflected as ' $i$, which tends to lose its initial glottal stop, and so is now phonologically identical to the static one, $i$, from PPn $*$ i. The conflation occurs in casual speech in Samoan. In careful speech glottal stop is retained in ' $i$.

ii. PPn *mai is reflected either as mei or mai (cf. note 2).

Samoan corresponds to Creissels' (2006) Pattern 2(a), with only two prepositions left: ablative mei/mai vs. essive-allative $i$. As we will see later, the two Samoan allomorphs for the

\footnotetext{
${ }^{2}$ This reconstruction is problematic: the ablative/ventive preposition is reflected as mei in several Polynesian languages belonging to two different subgroups: East Futunan, Marquesan, Mangarevan, etc. belonging to the Nuclear Polynesian subgroup, and Tongan belonging to the Tongic subgroup. Mei, however, is not attributable to the ancestor of either of these two subgroups; only *mai is reconstructable, that is, the form also reconstructed for the centripetal directional. One of the explanations for the shift *mai $>$ mei in some Polynesian languages is a phonological one: mei in Tongan, East Futunan, Marquesan, etc. can be explained as arising by an assimilation that happened independently several times; the change a $>$ e before $/ \mathrm{i} /$ is a common sporadic change, e.g. in Tongan PPn *qariki 'chief' > 'eiki, PPn *fafine 'woman' > fefine, etc. albeit this change has not happened in other words than mei in East Futunan, Niuafo'ou or Marquesan. Moreover, this change only happened in its prepositional use since the directional adverb remains mai in all these languages. According to A. Pawley (pers.com.), the difference which now exists between the two morphemes could be due to the stress, the phrase final adverb mai taking primary stress, while the preposition mei is unstressed.
} 
ablative meaning is a significant fact, since in some Polynesian languages the locative centripetal preposition is formally identical to the adverbial centripetal directional mai while in other languages, they diverge phonologically.

Let us first examine the functions of the locative prepositions with examples mostly from East Futunan, a language which keeps distinct the locative centripetal preposition (mei) from the adverbial centripetal directional (mai).

Depending on the category of the noun phrase they introduce, the three locative prepositions, which are built with suffixes in the following cases: $-a(+$ proper names and dual/plural independent pronouns), -ate (+ singular independent pronouns) if the noun phrase refers to a human entity considered as an individual, and $-\bar{O}$ if the human entity is considered as a location, similar to the French preposition chez 'at someone's place'. Hence, in East Futunan, the locative prepositions have the following forms: i/ia/iate/iō, ki/kia/kiate kiō, mei/meia/meiate/meiō.

It is the bare forms $i / k i / m e i$ that introduce toponyms and place nouns, whereas proper nouns and personal pronouns are introduced by suffixed forms. This word-class distinction has some implications for the expression of benefactive and Goal on the one hand, of dissociative and Source on the other hand. Cross linguistically, benefactive and Goal expressions are most often identically marked, and so are dissociative and Source expressions. Polynesian languages, by contrast, show morphological differences, even if the prepositions involved are basically identical.

In many languages, 'locative' prepositions often have several other functions, which, as we will see, have significant relations with the spatial relations. For example, the stative preposition is also used to express causal complements (cf. § 1.2.4), indicating the starting point of the cause, and the allative preposition is also used to introduce beneficiaries (cf. $\S 1.3 .2)$. In Polynesian languages there is, however, an asymmetry between the multifunctional 
Goal and Place prepositions and the quasi uni-functional Source preposition. This difference in uses has a direct consequence in discourse: the Source preposition occurs less often than the Goal and Place prepositions in both traditional stories and conversations.

\subsection{The source/ablative preposition}

In East Futunan, the preposition mei 'from, since, starting from' serves to introduce a centripetal dynamic Source which can never refer to the place where the figure is located. The Source may be either spatial, temporal, perceptive or even abstract.

\subsubsection{Source located in space}

The preposition mei introduces spatial complements after verbs of motion, such as 'au 'come' in the following examples, in which the figure (an object or a person moving in space) has left its point of origin, or is not yet in the point of origin mentioned in the discourse.

\section{EAST FUTUNAN}

$\begin{array}{llll}E & \text { 'au lātou mei } & \text { Ono. } \\ \text { NPST come } & \text { 3PL SOURCE } & \text { Ono } \\ \text { 'They are coming from Ono.' (They are no longer in Ono.) })^{3}\end{array}$

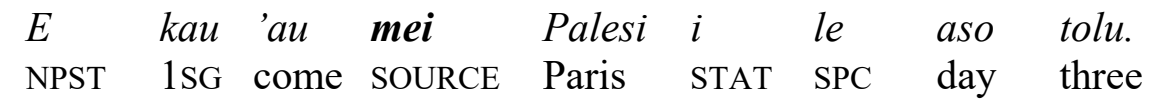

'I will come from Paris on the third [of the month].' (The speaker is not yet in Paris.)

E 'au a ia mei gāne'a kesekese o le Eulopa. NPST come ABS 3SG SOURCE place different POSS SPC Europe 'He comes from different places in Europe.' (He is no longer in Europe.)

In all the examples above, the verb associated with the ablative preposition is 'au 'to come'4. Other verbs of motion may also co-occur with the preposition mei, such as makape 'run' in (4) and ulu 'pass through, go in, go out, cross' in (5) as well as verbs of direct physical manipulation such as samuti 'prick out' in (6) or to'o 'take' in (7). In (5), it is mei that allows the hearer to understand that Soane is going out of his house, whereas in English,

\footnotetext{
${ }^{3}$ Unless otherwise indicated, all the examples are taken from my personal unpublished fieldnotes.

${ }^{4}$ The verb 'au < PPn *aqu 'come, reach, arrive' (Greenhill S.J. \& Clark R. 2011) often has the more general meaning of 'move from one place to another', and this explains its compatibility with the different prepositions.
} 
this role is played by the combination of a directional satellite and a preposition, 'out of', and in French by the verb sortir 'go out' followed by the preposition de 'from':

$\begin{array}{llllll}E & \text { makape } & \text { le } & \text { ta'ine } & \text { mei } & \text { le la'akau. } \\ \text { NPST } & \text { run } & \text { SPC } & \text { girl } & \text { SOURCE } & \text { SPC tree }\end{array}$

'A girl is running from a tree.' (The girl already left the tree.) (traj033_FUD)

E ulu a Soane mei lona fale.

NPST cross ABS Soane SOURCE his house

'Soane is just going out of his house.' (Soane is no longer in his house.).

Na samuti laku gā ika mei laku pā e Petelo. PST prick my CLS fish SOURCE my dish ERG Petelo 'Petelo pricked a bit of my fish out of my dish.' (Moyse-Faurie 1997:85)

$\mathrm{Na}$ kau to'o mai le kulo meiate koe. PST 1SG take CPTE SPC pot SOURCE 2SG 'I took away the cooking pot from your place.' (I am no longer in your place.)

\subsubsection{Fictive Source without actual motion}

With verbs expressing a static position such as nofo 'sit, live somewhere' in (8), taulaki 'moor' in (9) or eke 'sit' in (10), or with verbs of communication or perception as in (11-13), the dynamicity is fictive, that is, the use of mei only expresses motion in the auditory or visual perception of the speaker:

E nofo le fenua fuli mei le Kolofau. NPST stay SPC people all SOURCE SPC Kolofau 'Everyone lives at the mount Kolofau.' (The speaker is located elsewhere.) (MoyseFaurie 1997:55)

(9) E taulaki a vaka mei tai. NPST moor ABS boat SOURCE sea

'Boats are moored in the open sea.' (The speaker sees them.) (id.:206)

(10) Ko lona ta’ine la fa’i leia $e$ eke mei le fatu la. PRED her daughter EMPH RESTR DEIC NPST sit SOURCE SPC stone EMPH '[The boat is arriving in Alofitai], it is her daughter who is sitting on the stone.' (The mother is still on the boat.)

(11) E sola fa'i a Veka aia ki 'uta, o tagi mei le 'one. NPST flee RESTR ABS Veka DEIC GOAL inland COMP cry SOURCE SPC sand 'Veka (Rallus sp.) flees towards the land, and cries from the beach.' (towards someone still on the sea who can hear it).
O 'oki ti kalaga a ia mei ai. and finish then call ABS 3SG SOURCE ANAPH 'And then he shouts from there.' (The hearer is at the opposite extremity.) 
Ko le gako ku kalalā mei le kulo.

PRED SPC grease PFV crackle SOURCE SPC cooking.pot

'The grease crackles in the cooking pot.' (Moyse-Faurie 1997:85)

\subsubsection{Temporal Source}

Typically, mei introduces a noun phrase referring to a place which specifies the origin of an object or a person. However, mei can also introduce a temporal location, after verbs which do not necessary refer to motion. Hence, in example (14) below the fact of motion is conveyed by the nominalised phrase lau' au 'your coming', which is introduced by mei:

$$
\begin{array}{lllll}
\mathrm{Na} & \text { lekiaise } & \text { kau kai mei lau 'au. } \\
\text { PST NEG } & \text { 1SG eat SOURCE your come } \\
\text { 'I had not eaten yet when you arrived.' (Moyse-Faurie 1997:101) }
\end{array}
$$

\subsubsection{Abstract or metaphoric Source}

The preposition mei may also introduce a noun phrase referring to former events or a metaphoric Source. It then means 'related to', 'concerning' rather than 'from':

$$
\begin{array}{llll}
E \quad k a u \quad m a f a ' a & \text { meia } & \text { Petelō. } \\
\text { NPST 1SG descend.from SOURCE } & \text { Petelo } \\
\text { 'I am the descendant of Petelo.' } &
\end{array}
$$

$$
\begin{aligned}
& \text { Ku kau sao mei le tu'utämaki. } \\
& \text { PFV 1SG safe SOURCE SPC accident } \\
& \text { 'I am safe concerning the accident.' (Lit. I am safe from the accident) (Moyse-Faurie } \\
& \text { 1997:85) }
\end{aligned}
$$

The semantics and functions of the dynamic centripetal preposition are similar in the languages where it occurs as mai, that is, formally identical to the directional adverb 'toward the deictic centre' (cf. §2.1.1). We will see that this formal identity, due to the same origin (cf. note 2), does not extend to their functional and semantic specificities. Examples from East Uvean below show the use of mai as the Source preposition introducing place names (17), temporal notions (18), objects (19) or abstract notions (20-21):

\section{EAST UVEAN}

Ko te 'ù moa mai Halalo. PRED SPC CLS chicken SOURCE Halalo 'They are chicken from Halalo.' 
$(18)$

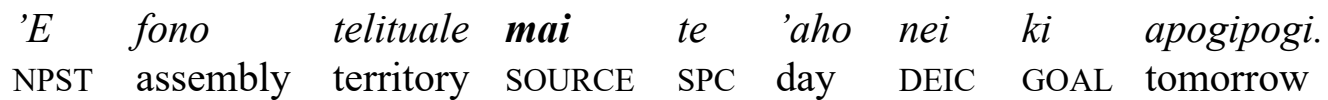
'The territorial assembly will meet from today until tomorrow.'

(19) 'E 'alu mo koe mai te magisi ki te manu. NPST go with 2SG SOURCE SPC tubers GOAL SPC animal 'You are going to take with you [everything starting] from the tubers up to the animals.'

'E iai te fafine ne'e hao mai
NPST exist SPC woman PST survive SOURCE SPC war
'There is a woman who survived from the war.'

Ko Vaka'ana ko he tagata ia mai te Ha'avakatolō.

'Vaka'ana, he is one of the man of the Ha'avakatolo clan.' (Moyse-Faurie 2016:78)

To summarise, the ablative/dynamic centripetal preposition conveys one main piece of information: the point of reference must be different from the deictic centre/the figure, and the motion (real or fictive) is calculated from the point of reference toward the deictic centre. Its meaning is always related to the Source of motion or physical manipulation, and it has no other function.

\subsection{The static/essive preposition}

\subsubsection{Spatial localisation}

As a locative preposition, $i$ expresses a static spatial localisation: 'at, in, on, between'. Recall that locative prepositions have different suffixes when introducing noun phrases referring to space: $i+$ place names (22), ia + proper nouns and dual/plural pronouns (23), iate + singular pronouns and $i \bar{o}+$ someone's place (24).

EAST FUTUNAN

$$
\begin{array}{llllll}
E & \text { nofo } & a & i a & \boldsymbol{i} & \text { Ono. } \\
\text { NPST stay } & \text { ABS } & \text { 3SG } & \text { STAT } & \text { Ono } \\
\text { 'He lives in Ono.' } & & &
\end{array}
$$

(23) E tauloto le sau ia Manafa mo Sa'atula. NPST sit with s.o. SPC king STAT Manafa and Sa'atula 'The king is sitting between Manafa and Sa'atula.' (Moyse-Faurie 1997:76) 
The example (24) expresses a motion event, and the role of the static preposition $i \bar{o}$ is to specify the place where the speaker is living:

$\begin{array}{lllllll}E & \text { sili } & \text { le } & \text { motokā } & \text { a } & \text { Palatina } & \text { iō 'oku. } \\ \text { NPST go.by } & \text { SPC } & \text { car } & \text { POSS } & \text { Palatina } & \text { STAT } & \text { 1SG.INDEP } \\ \text { 'Palatina's car is passing by my place.' (id.:86) }\end{array}$

\subsubsection{Temporal localisation}

The static preposition has no allomorphic suffixes when it introduces a temporal localisation, which may refer to a present, past or future event, as in (25) and (26).

E kau tau mai ki leinei $\boldsymbol{i}$ le
NPST $1 \mathrm{SG}$ dock CPTE GOAL here
'I will arrive here on Sunday.'

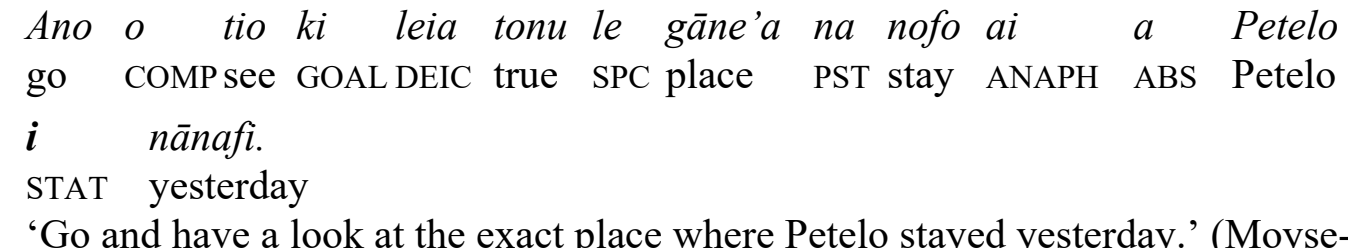
Faurie 1997:23)

\subsubsection{Expression of the Source}

As seen earlier, East Futunan has three different locative prepositions, primarily dedicated to three main functions, namely essive, ablative or allative. What is of interest, however, is the possible use of the same preposition $i$ (glossed STAT) in some non-ambiguous situations, for both the static localisation (essive meaning) and the Source (ablative meaning), different from the Goal (allative meaning), which can only be marked with the preposition $k i$ as we will see in $§ 1.3$. As stated by Bourdin (1997:189) after a similar Palauan example, we can say that "specification of the Source may be said to be less straightforward here than specification of Goal”.

As shown in (27) and (28), the essive preposition can indeed express the Source, as long as the figure has not yet left the point of origin. 
(27)

E ulu atu le ta'ine $\boldsymbol{i}$ loto o le ana. NPST cross CFG SPC girl STAT inside POSS SPC cave 'A girl is getting out of the cave (going away from the speaker who is staying in the cave).' (traj025_FUD)

E kau 'au $i$ Palesi $i$ le aso tolu.

NPST 1SG come STAT Paris STAT SPC day three

'I will come from Paris on the third.' (The speaker is in Paris.)

In this context, a Goal may be expressed in addition:

$$
\text { E kau 'au i Niumea ki 'Uvea. }
$$

NPST 1SG come STAT Noumea GOAL Wallis

'I will come from Noumea to Wallis.' (The speaker is still in Noumea and intends to go to Wallis.) (Atonio Takasi, pers. com.)

Note that if the ablative preposition mei is used instead of the essive $i$ to introduce

Niumea in the example (30), the meaning is similar, but the speaker cannot be located in

Noumea.

$$
\text { E kau 'au mei Niumea ki 'Uvea. }
$$

NPST 1SG come STAT Noumea GOAL Wallis

'I will come from Noumea to Wallis.' (The speaker is not in Noumea, but intends to go to Wallis from Noumea.) (Atonio. Takasi, pers. com.)

The possibility of expressing the Source in both ways - that is, using the static

preposition or the Source preposition - also exists in Tuvaluan, but according to Besnier (2000:342), the restrictions for each use are not as strict as they are in East Futunan: "The choice between $i$ and mai (or the combination mai $i$ ) as a marker of source is not structurally determined, since either preposition can be used in most cases without affecting grammaticality. Rather, mai is used to mark the most immediate origin, whereas $i$ does not carry such a connotation":

TUVALUAN $^{5}$

$\begin{array}{llll}K \bar{o} & \text { vau } & \boldsymbol{m a i} / \boldsymbol{i} & \text { Fìti. } \\ \text { INC } & \text { come } & \text { SOURCE/STAT } & \text { Fiji }\end{array}$

'[He]'s come from Fiji [and Fiji was his last port of call] / [and Fiji was his point of departure].' (Besnier 2000:342)

\footnotetext{
${ }^{5}$ To conform to other transcriptions, I have adapted the glosses in the Tuvaluan sentences.
} 
East Futunan and Tuvaluan also differ when the Goal is expressed together with the Source. In East Futunan, the preposition $i$ can still express the Source when the Goal is overtly expressed: the initial point of departure is introduced by $i$, and the final Goal by $k i$ as in (30), or in the following example.

\section{EAST FUTUNAN}

$$
\begin{aligned}
& \text { E sopo ake le toe } \boldsymbol{i} \text { aluga o le pàáa fatu } \\
& \text { NPST jump TRANSV SPC child STAT above POSS SPC wall stone } \\
& \text { tau'aluga ki loto o le tai. } \\
& \text { high up GOAL inside POSS SPC sea } \\
& \text { 'The child jumps from the cliff into the sea.' (traj064_FUD) }
\end{aligned}
$$

However, this is not possible in Tuvaluan where only mai can express the Source in such a context: "When both source and destination are specified, mai must be used, and $i$ cannot appear" (Besnier 2000:342):

TUVALUAN

Mãtou ne fōllau mai Nanumea ki Nanumaga $i$ te pō sefulu. 1PL.EXCL PST sail SOURCE Nanumea GOAL Nanumaga STAT SPC day ten

'We sailed from Nanumea to Nanumaga on the tenth.' (Besnier 2000:342)

There is indeed a conflation in the meaning of the two prepositions. That is, the essive preposition $i$ and the ablative preposition mei/mai are both able to express the Source; but there are restrictions, since, at least in East Futunan, the preposition $i$ can only express the Source if and only if the figure has not left the initial point, and the verb must be a motion verb. The conflation of essive and ablative meanings is hence only partial.

Nikitina (2009:1114-1116) discusses the semantic relationship between the three major locative roles, also defining different patterns of encoding and cases of conflation. She concludes that in any case, a similar ordering of the three locative roles is expressed, represented on the semantic map (1) (id. 1116), in which "the greater distance between Place and Source compared to the distance between Place and Goal reflects the fact that identical 
encoding of goals and static locations is typologically more common than identical encoding of static locations and sources" (id. 1117):

\section{Goal---Place--------------Source}

East Futunan and Tuvaluan data fits with the ordering of the semantic map (1) above. Yet, the greater distance is not between the Source on the one hand and the Goal and Place on the other hand, but rather, as shown on the map (2) below, between Goal on the one hand and the Place and Source on the other hand:

2. Goal-------------Place---Source

\subsubsection{Other functions of the static/essive preposition}

An explanation of the use of the static/essive preposition $i$ in the expression of the Source of the motion could lie in the fact that this preposition is also used to express causal complements (34 and 35) and comparison (36).

$$
\begin{aligned}
& \text { Kua konā oku mata i le afi. } \\
& \text { PFV prick my eye STAT SPC fire } \\
& \text { 'My eyes are stinging because of the fire.' (Moyse-Faurie 1997:81) }
\end{aligned}
$$

$$
\text { Kua mavete le laugutu o le li'ua } \boldsymbol{i} \text { puaka. }
$$
PFV break.down SPC bank POSS SPC river STAT pig 'The river bank broke down because of the pigs.' (id.)

$$
\begin{array}{lllllll}
E & \text { kese } & \text { lou } & g \bar{a} & \text { kie } & \boldsymbol{i} & \text { lo'oku. } \\
\text { NPST different } & \text { your } & \text { CLS } & \text { loincloth } & \text { STAT } & \text { mine }
\end{array}
$$

'Your loincloth is different from mine.' (Moyse-Faurie 2010:309)

Note that in Tuvaluan (Besnier 2000:325), it is the ablative preposition mai which can optionally express the cause instead of $i$, as in (37).

TUVALUAN

$$
\text { Toku masaki ne māfua i/mai te kai valea } i \text { te fāipoipoga. }
$$
my sickness PST originate STAT/SOURCE SPC eat stupid STAT SPC wedding 'My being sick stems from eating thoughtlessly at the wedding.' (Besnier 2000:325)

The relation between the expression of the cause and the expression of the Source is indeed quite obvious, and in comparative situations, the element which serves as the point of 
comparison is also considered as the Source, as the English translation of the example (36) shows. As a Source marker, the meaning of the preposition $i$ could be described as an initial point, a 'starting from', in a static point of view, before any motion occurs.

Besides, it is the overlap in the semantics of the two essive and ablative prepositions which can explain their possible combination (mai $+i$ in Tuvaluan and possibly in Samoan, see §1.4). Still, in most of the Polynesian languages, three different prepositions do exist separately, each having a main meaning: essive vs ablative vs allative. As we will see in the next section, the allative preposition is the only one of the three that can express the Goal, but neither the Source nor the localisation.

\subsection{The goal/allative preposition}

\subsubsection{Allative meaning}

As a locative preposition $k i$ has a dynamic, centrifugal meaning: 'towards, at, on, in'. It can introduce toponyms (38), locative nouns (39), personal names (40), common or abstract nouns (41). The Goal can be specific, or it can just consist of a direction, either away from the deictic centre (as in most examples) or towards the deictic centre.

\section{EAST FUTUNAN}

$\begin{array}{lllllll}E & \text { motou ano } \quad \boldsymbol{k i} & \bar{A} \text { lofi } & i & \text { kalasini } & i & \text { apogipogi. } \\ \text { NPST 1PL.EXCL go GOAL Alofi } & \text { STAT motor.boat } & \text { STAT } & \text { tomorrow } \\ \text { 'We will go to Alofi on a motor boat tomorrow.' }\end{array}$

$\mathrm{Na}$ ulu a ia ki fale o ina to'o le sele. PST cross ABS 3SG GOAL house COMP 3SG take SPC knife 'He entered the house to take a knife.'
E likalika fa'i a le toe la kae 'au kia Paulo. NPST dread RESTR ABS SPC child EMPH but come GOAL Paulo 'The child is a bit afraid but he still goes towards Paulo.'

The Goal preposition $k i$ is also used in specific temporal situations, as in (41), to introduce an approaching time: 
(41)

Ko le toe kuata ki le ola tasi.

PRED SPC remaining quarter GOAL SPC hour one

'It is a quarter to one.' (Lit. it is the remaining quarter towards hour one)

There are no restrictions on the compatibility of $k i$ with different verbs, as is shown in the following examples with the verb 'au 'come', which we have previously seen occurring with the ablative and essive prepositions. (See also 40)

$$
\begin{array}{lllll}
K o \quad l e \quad \bar{a} u \quad e \quad \text { 'au } \quad \text { ki } & \text { kunei. } \\
\text { PRED SPC } & \text { smoke NPST come GOAL } & \text { here } \\
\text { 'The smoke is coming towards here.' }
\end{array}
$$

E taputu le 'au a Lita kiō Soana.

NPST frequent SPC come POSS Lita GOAL Soana

'The visits of Lita to Soana's place are frequent.' (Lit. is frequent the coming of Lita to Soana's place)

\subsubsection{Other functions}

Just as the static locative preposition (cf. section 1.2), $k i$ has several other uses: it introduces objects of middle verbs ${ }^{6}$ (44), beneficiaries (45), and instrumental complements (46).

\section{EAST FUTUNAN}

$$
\begin{array}{llllll}
\text { E loto le } & \text { ta'ine } \boldsymbol{k i} & \text { se } & \text { fakatagi } \\
\text { NPST want SPC } & \text { young.girl } & \text { OBL NSPC radio }
\end{array}
$$

'The young girl would like a radio.' (Moyse-Faurie 1997:31)

$$
\begin{array}{llllll}
E & \text { kau tufa a lole } & \text { ki } & \text { toe } \\
\text { NPST } & 1 \mathrm{SG} \text { distribute ABS candy BEN children } \\
\text { 'I am distributing candies to the children.' '(id.:85) }
\end{array}
$$

E fuefue a le finematu'a ki lona faioa.
NPST use.a.fan ABS SPC old.woman INSTR her fan
'The old woman is fanning herself with her fan.' (id:83)

\subsection{Combination of two prepositions}

In East Uvean, as in East Futunan, no combination of two of the three locative prepositions $-i$ (essive), $k i$ (allative) and mei/mai (ablative) - is allowed in the same phrase. The only languages in which such a combination is said to be possible are Samoan and Tuvaluan,

\footnotetext{
${ }^{6}$ In the Polynesian linguistic tradition, middle verbs are verbs of emotion, sensation, perception and communication which enter specific constructions, with an argument - the experiencer - in the absolutive case and an argument - the patient or stimulus - in the oblique case.
} 
where the ablative preposition mai can be followed by the essive $i$. In Tuvaluan, according to Besnier (2000:342), there is no difference in meaning in the use of simple vs complex preposition. He notes that the preposition "mai combines optionally with $i$ to form the compound mai $i$, which has exactly the same meaning as mai, although it is slightly more formal and deliberate".

For Samoan, Hovdhaugen and Mosel (1992:147) note that "Mai [the source preposition] is frequently used in combination with the locative-directional preposition $i$ 'in, from'...". The examples given, however, are all from Biblical Samoan: mai ia te, mai iā, which might be better analyzed as allomorphs of a unique preposition mai, which has maiate $(+$ singular pronouns) and mai $\bar{a}(+$ plural pronouns and proper names) as allomorphs, as it is the case in other Polynesian languages.

In Marquesan (Central Eastern Polynesian), the Source preposition can combine with two other prepositions, the locative preposition 'io 'at or towards place of $X$ ' as in (47), or the preposition $m a$ "which expresses the passage through a location or place" (Cablitz 2006: 450) as in (48):

MARQUESAN

Ua he'e Teiki mei 'io he ko'oka mai tihe 'io te ha'e pure. PFV go Teiki SOURCE AT NSPC trough CPTE arrive AT SPC house prayer 'Teiki has left from the trough arriving at the church.' (Cablitz 2006:450)
Mei ma tai mai nei au. SOURCE PREP sea CPTE/come? DEIC 1SG
'I am just coming (somewhere) from the seaward place.' (id.:451)

To conclude on the three locative adpositions, one can observe that the Source/ablative and the static/essive prepositions can combine in a few languages such as in Tuvaluan, Samoan and Marquesan, or can partly have the same meaning and function as is the case in East Futunan as far as the expression of the Source is concerned, even if there are important restrictions concerning the position of the figure. By contrast, the Goal/allative preposition 
cannot combine with any of the two other locative prepositions, and this asymmetry is noteworthy.

\subsection{Complex prepositions}

There are two kinds of complex prepositions: the first type consists of a preposition plus a nominal lexeme, while the second one consists of the preposition plus a verbal lexeme.

\subsubsection{Complex 'nominal' prepositions}

These are complex prepositions derived from local nouns referring to internal parts of objects, such as 'inside', 'top', 'bottom'. They include one of the three locative prepositions, followed by a possessive noun phrase introduced by the possessive inalienable preposition $o$. With local nouns, as with toponyms, the prepositions are in their bare forms. Below are examples showing the use of the Source and the Goal prepositions:

\section{EAST FUTUNAN}

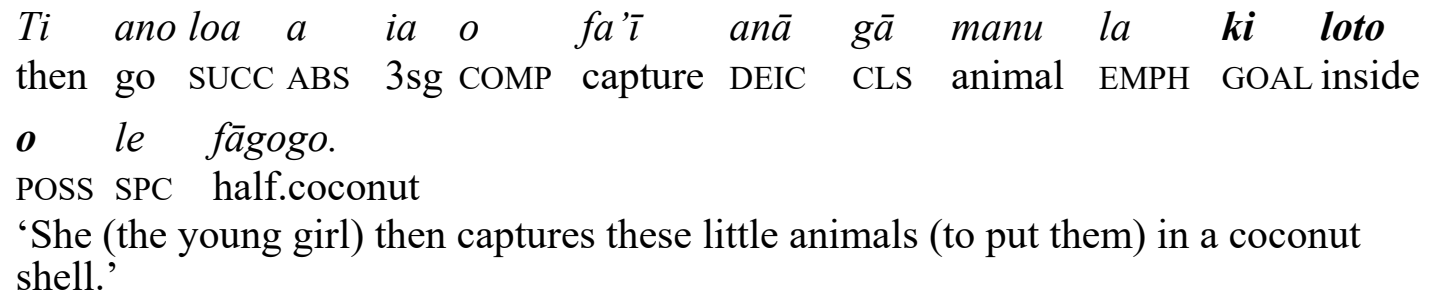
then go SUCC ABS 3sg COMP capture DEIC CLS animal EMPH GOAL inside o le fāgogo. POSS SPC half.coconut 'She (the young girl) then captures these little animals (to put them) in a coconut shell.'

(50) O logo a Sigave kua fai kava a Alo mei aluga o le ma'uga. and hear ABS Sigave PFV make kava ABS Alo SOURCE top POSS SPC mountain 'People from Sigave then heard that people from Alo were preparing kava from the top of the mountain.'

As far as complex nominal prepositions are concerned, the same symmetry between Goal, Source and Place is mentioned by Bourdin (1997:199) for Rapanui, another Polynesian language described by Du Feu (1996): the different complex nominal prepositions are all compatible with the three basic locative (essive, allative and ablative) prepositions. 


\subsubsection{Complex 'verbal' prepositions}

Complex verbal prepositions combine a conjunction (complementizer $o$ or $k e$ 'that, in order to'), a verb of motion or a verb of position and the Goal/allative preposition ki. In East Futunan and East Uvean, several verbs may be part of such complex prepositions: $k a k u$ 'reach, arrive at', talu 'originate', tu'u 'stand up', 'au 'come', tuku 'leave', tau 'reach'. All combinations imply that the destination has been reached, with differences in the geographical situation of the figure involved in the destination: $o$ kaku $k i$ 'up to on a horizontal axis' as in (51), o tu'u $k i$ 'up to a standing position' in (52), o tau $k i$ 'up to the landing destination' in

\section{EAST FUTUNAN}

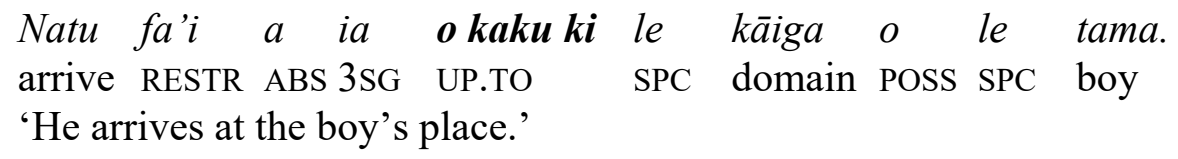

E ifo lenā le fā moamoa la otu'u ki le 'one. NPST go.down DEIC SPC CLS inflorescence EMPH UP.TO SPC sand 'The inflorescence of the banana tree goes down to the sand.' (Moyse-Faurie 1997:90)

$\begin{array}{lllllllll}\text { Ti 'aga } & \text { a } & \text { ia } & \text { o } & \text { fakato'o } & k i & \text { le } & \text { fafine } & \text { la } \\ \text { then face } & \mathrm{ABS} & 3 \mathrm{SG} & \mathrm{COMP} & \text { hand.over } & \mathrm{BEN} & \mathrm{SPC} & \text { woman } & \mathrm{EMPH} \\ k \text { ano } \quad \text { o tau } \boldsymbol{k i} & \text { se } & \text { 'uluvao. } & & & & \\ \text { CONJ go } & \text { UP.TO } & \text { NSPC } & \text { bush } & & & & \end{array}$

'Then she hands [it] over to the woman so that she goes [with it] up to the bush.'

Following Bourdin (1997:194), we can say that the complex verbal locative

prepositions specifically encode Goal-Extent, that is, all the way between the starting point up

to the Goal is taken into account. By contrast, in combination with the Source/ablative preposition - mai in East Uvean and mei in East Futunan -, only the verb talu 'originate' is attested, deriving the complex temporal preposition talu mai/mei 'since', optionally introduced by the conjunction $o$.

\section{EAST UVEAN}


Kua $i \quad$ Futuna talu mai anaāfi.

PFV STAT Futuna SINCE yesterday

'He is in Futuna since yesterday.'

\section{EAST FUTUNAN}

$$
\begin{array}{lllllll}
\text { Lekiaise tō se afā } & \text { (o) talu mei fêtu'u } & e & \text { ono. } \\
\text { NEG fall NSPC } & \text { cyclone SINCE year NPS } & \text { six }
\end{array}
$$

'No cyclone has yet occurred since six years.' (Moyse-Faurie 1997:89)

With respect to the combination of locative prepositions with verbs in order to form complex adpositions, the expression of the Goal is much richer than the expression of the Source, since the latter is limited to the temporal domain and can combine with only one verb, talu 'originate'. I have found no complex verbal locative prepositions including the stative/essive preposition.

\subsection{Conclusion on the prepositions occurring in spatial relations}

The three prepositions investigated in the first section share some properties but differ in others. All of them are compatible with motion, posture or physical manipulation verbs, such as 'au 'come', ano 'go', nofo 'stay' or to'o 'take'; they show no restrictions as far as the word class (independent pronouns, toponyms, local nouns, proper nouns or common nouns) is concerned and show the same morphological flexions. Of the three prepositions, the Source/ablative preposition is the least diverse in its semantics and functions, and it has the heaviest phonological weight, with two syllables instead of one for the other prepositions. The essive and the allative prepositions have multiple uses, introducing diverse adjuncts as well as oblique arguments. Yet, only the essive preposition is used in comparative constructions or to introduce causal complements, and only the allative preposition marks instrumental.

As already mentioned, in Samoan, two of these prepositions tend to fuse due to a phonological reduction $(\mathrm{k}>\mathrm{P}>\varnothing$, hence the goal/allative $k i>? i>i$, becoming formally similar to the static/essive preposition $i$ ). To conclude this first section, we can note that there are more complex prepositions to express Goal than to express Source. 


\section{Directionals}

The core function of directionals is "to signal the direction of translational motion of a physical entity in the action encoded by the verb that heads the verb complex" (Lichtenberk, 2003:153), whether or not the head verb encodes the event of motion. Each directional may refer either to the physical path followed by a moving figure, or to the mental path followed by the speaker or the observer, either in space or in time; in narratives, they may also position a participant with respect to another. They are very frequent in imperative clauses, and are not restricted to a specific verb category, being compatible with verbs of emotion or perception, for example. Among their non-spatial uses, they occur in comparative or superlative constructions, and may also express reflexivity and reciprocity, or replace arguments.

Personal/deictic markers, local markers and geocentric markers are the three different types of directionals found in Oceanic languages. Not all languages have these three types, but all have at least two or three personal/deictic directionals, which are our main concern in this paper.

According to Pawley $(1973 ; 2003)$ and Ross (2004:194), most directionals are said to be derived from verbs occurring in serial verb constructions. This explains why directionals are always postposed to the verb, either as part of the predicate phrase, or in a nominalised construction. The grammaticalization from verbs of motion into directionals was already achieved in Proto Oceanic for POc *mai 'come' > 'towards speaker', *[w]atu 'go away'> 'towards addressee', *sake 'go upward' and *sipo 'go downward'; both functions, verbal and adverbial, were maintained in some Polynesian languages, at least for *mai, *sake and *sipo. In some cases, directionals have undergone phonetic reduction as is the case in East Uvean, where the verb hifo 'go downward', borrowed from Tongan, has grammaticalized into the directional ifo 'downward' (cf. examples (65) and (66)). 


\subsection{Personal/deictic directionals}

Personal directionals vectorise an event toward a specific participant. In some Polynesian languages, three personal directionals form a paradigm, in a same person oriented deictic system as the demonstratives. In East Uvean for example: mai 'towards the speaker; towards the point of reference of the discourse, hither', glossed as CPTE for centripetal (56), atu 'towards the addressee, away from the point of reference of the discourse, thither' glossed as CFG for centrifugal (57), and age 'away from the speaker or the addressee' glossed as TRANSV for transverse (58):

\section{EAST UVEAN}

$$
\begin{array}{llllll}
\text { Ne'e ina } & \text { toho mai tona kupegá. } \\
\mathrm{PST} & \text { 3SG } & \text { pull } \mathrm{CPTE} \text { his fishnet }
\end{array}
$$

'He brought back his net towards him.' (Moyse-Faurie 2016:156)

$$
\begin{aligned}
& \text { 'E au fia 'alu atu, kae au mataku. } \\
& \text { NPST 1SG feel like go CFG but 1SG fear } \\
& \text { 'I feel like going towards you but I am afraid.' }
\end{aligned}
$$

(58) Ko ai te matu'a 'aē 'e 'alu agé? PRED who SPC old man DEIC NPST go TRANSV 'Who is that old man passing by?' (Moyse-Faurie 2016:158)

Let us look more precisely at the meanings and uses of the personal/deictic directionals before examining their compatibilities with the different locative prepositions.

\subsubsection{The centripetal directional 'hither'}

The centripetal directional mai is used for situations in which the participant belongs to the sphere of the speaker or the sphere of the deictic centre, as in (59) and (60).

\section{EAST UVEAN}

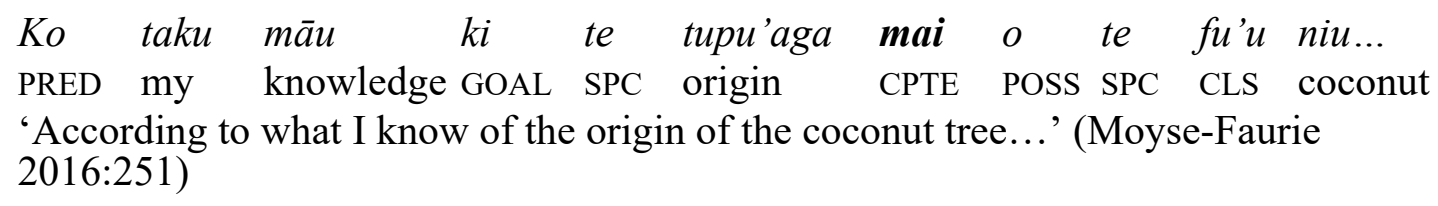

\section{EAST FUTUNAN}


(60) $E$ ulu mai le ta'ine ki loto o le ana. NPST cross CPTE SPC girl GOALinside POSS SPC cave 'A girl is entering the cave (towards the deictic centre who is staying in the cave).' (traj22_FUD)

\subsubsection{The centrifugal directional 'thither'}

The centrifugal directional atu is used for situations regarding the sphere of the addressee, whether the latter is still present (61) or whether he has already left the deictic centre (62).

\section{EAST UVEAN}

$$
\begin{aligned}
& \text { To'o atu te heka'aga 'aenī. } \\
& \text { take CFG SPC chair DEIC } \\
& \text { 'Take the chair (which is) near me.' (Moyse-Faurie 2016:87) }
\end{aligned}
$$

\section{EAST FUTUNAN}

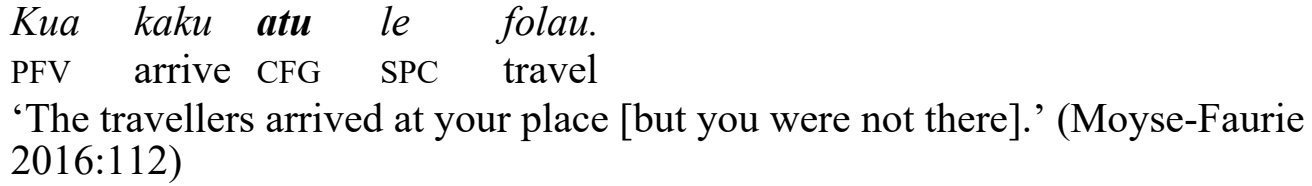

The directional atu can also occur in order to indicate that the motion is undertaken by the figure, who has moved away from the speaker and his circle:

$\begin{array}{llllllll}\text { Nao } & \text { mavae } & \text { atu } & \text { nei } & \text { fua } & \text { a } & \text { Petelo } & \text { mo tātou. } \\ \text { IMM.PST separate } & \text { CFG now just } & \text { ABS } & \text { Petelo } & \text { with } & \text { 1PL.INCL } \\ \text { 'Petelo just left us.' (Moyse-Faurie } & \text { 1997:95) }\end{array}$

\subsubsection{The transverse directional 'away'}

In East Uvean, the directional age is used for situations belonging neither to the sphere of the speaker nor to the sphere of the addressee. It may also refer to a direction along the coast, neither towards inland nor towards the sea.

\section{EAST UVEAN}

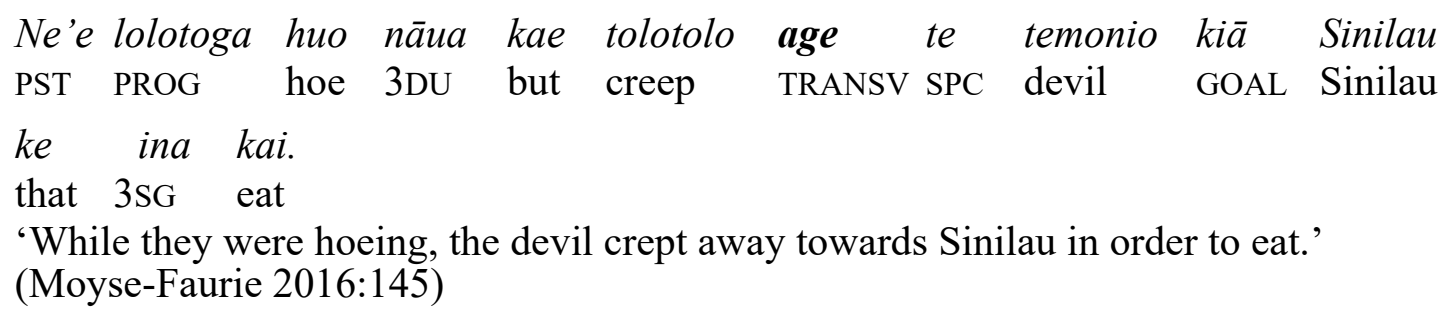




\subsection{Local directionals}

Local directionals are defined in reference to a physical feature of the local situation:

up/down, in/out. In Polynesian languages, only the up/down axis is grammaticalised by using directionals, whereas in Melanesian languages such as Mwotlap spoken in North Vanuatu (François 2003) or Xârâcùù spoken in New Caledonia (Moyse-Faurie 1995) for example, the in/out axis also relies on directionals.

\section{EAST UVEAN}

Pea sio ake te fafine pea ina ui ke hifo ifo. and see UP SPC woman and 3SG say that go.down DOWN 'And a woman saw him up there and asked him to come down.' (Moyse-Faurie 2016:158)

$$
\text { Ne'e 'alu ifo ia Tagaloa mai lagi o 'a'au tona kupegá. }
$$
PST go DOWN ABS Tagaloa SOURCE sky COMP throw his net 'Tagaloa went down from the sky and threw his fishing net'. (id.:190)

In some Oceanic languages, geocentric directionals are defined in reference to absolute (geographic) coordinates: seaward, landward (Ozanne-Rivierre 1998; François 2003). They are not attested in Polynesian languages. Corresponding expressions are PPn *tahi 'sea', and *quta 'ashore, inland', but like other locatives (including toponyms), they must be preceded by a preposition. In Polynesian languages, directionals refer to an axis (PPn *hake 'upwards, towards the land', PPn *hifo 'downwards, towards the sea'), and must be distinguished from locatives, which refer to a place and do not behave as directionals. In East Uvean for example locative nouns can be preceded by any of the three locative prepositions to form locative complements such as mai tai 'coming from the sea'; $k i$ 'uta 'towards inland'; $i$ 'uta 'inland' as in (67).

\section{EAST UVEAN}

$$
\begin{aligned}
& \text { Ne'e mā } \quad \boldsymbol{i} \\
& \text { PST 1DU.EXCL } \\
& \text { 'Both of us were inland.' }
\end{aligned}
$$




\subsection{Main uses of directionals}

The three (centripetal, centrifugal and transverse) personal directionals are often call deictic directionals, because they entail reference to the deictic centre. As shown by Hooper (2004) for Tokelauan, the deictic centre needs not to be the subject; rather, it indicates the point of view of the main protagonists of the discourse, as in the Tokelauan example (68), in which the experiencer is not overtly mentioned, but is known by the context to be the narrator and his companions:

TOKELAUAN

Ko te taimi kua oho mai te lā, e kitea mai
PRED SPC time PFV rise CPTE SPC sun NPST see CPTE
te oneone o $\quad$ te matāfaga.
SPC sand POSS SPC beach
'At the time that the sun rose, the sand of the beach was visible to us.' (Hooper
2004:1755-1756)

The core function of these directionals is to express physical motion through space.

They are also very often used to express directionality of events that do not involve translational motion of physical objects, such as perception and speaking; hence in East Uvean, age often occurs after verbs of speech such as 'say', 'tell', 'agree', etc.:

\section{EAST UVEAN}

$$
\begin{aligned}
& \text { Pea 'ui age leva e te tagata 'aē ne'e ha'u... } \\
& \text { and say TRANSV EMPH ERG SPC man DEIC PST come } \\
& \text { 'The man who was arriving told him...' (Moyse-Faurie 2016:138) }
\end{aligned}
$$

Let us also mention one of the local directionals, which has a specific form in East

Uvean: ake 'upwards', 'towards land when at sea', as shown in (70).

$$
\begin{aligned}
& \text { Pea heheka nāua ki te vaká o foe ake ki } \quad \text { Vailala. } \\
& \text { and sit(PL) 3DU GOAL SPC boat COMP paddle UP GOAL Vailala } \\
& \text { 'And both of them climbed in the boat and paddled towards Vailala.' (Mayer } \\
& \text { 1976:106) }
\end{aligned}
$$

Just as the 'personal' directionals do, the local directionals may express directionality without physical motion (Talmy 2017's fictive motion), as is the case after verbs of speech or 
perception, as shown in the following example East Uvean with the local directional ifo 'downwards':

Pea logo ifo ia Puakavahe kua lavea ia Mütao. and listen DOWN ABS Puakavahe PFV hurt ABS Mutao 'Then Puakavahe heard from downwards that Mutao was hurt.' (Henquel 1910:57)

Most of the other Polynesian languages only have four directionals, because of the merging of PPn *aye 'away from both the speaker and the addressee' (deictic meaning); 'along, obliquely' ('transverse' geocentric meaning) and PPn *hake 'upwards'. This is the case in Tuvaluan, Māori, or Marquesan. Note that *aye doesn't seem to have a verbal origin, in contrast to ake <*hake 'go up'.

In East Futunan, only three directionals are attested: mai 'hither', 'towards the deictic centre', 'towards the speaker' or, in narratives, 'towards the place or the figure the speaker is talking about'; atu 'thither'; and ake which conflates the upwards local meaning and the deictic transverse meaning. Hence, in East Futunan, there are no local directionals strictly speaking, since ake is mostly used as a deictic directional (examples (72) and (73)), even if it is formally equivalent to the East Uvean 'upwards' directional and may have a local upward meaning in some contexts.

\section{EAST FUTUNAN}

$$
\text { Kua kaku ake le folau. }
$$
PFV arrive TRANSV SPC travel

'The travellers arrived at other people's place/over there.' (Moyse-Faurie 1997:113)

$$
\begin{aligned}
& \text { Seu ake sana ne'akai! } \\
& \text { serve TRANSV his food } \\
& \text { 'Serve him his food!' (id.) }
\end{aligned}
$$

For Māori, Bauer (1997:350) lists mai 'hither, towards speaker', atu 'away from speaker', ake 'upwards from speaker' and iho 'downwards towards speaker', which makes two centripetal and two centrifugal directionals. The first pair concerns the horizontal level, while the second concerns the vertical level. 
MĀORI

(74) E kō, hoki mai, hoki mai... VOC girl return CPTE return CPTE

'Daughter, come back, come back...' (Bauer 1997: 351)

He kura pae āku, nō reira kāre e whakahoki-a atu. CLS feather come.ashore my belong there NEG IPFV CAUS.return-PASS CFG 'Feathers washed ashore are mine, and so I'm not going to return them.' (id.)

(76) Ka hoki ake anō te kōtiro rā ki te pā... TAM return UP again SPC girl DEIC GOAL SPC elder

'The girl returned up to the elder again...' (Bauer 1997: 352)

(77) Peke iho ki runga $i$ te moenga! jump DOWN GOAL top AT SPC mattress

'Jump down unto the mattress.' (id.)

According to Cablitz (2006), Marquesan also has four directionals: mai 'towards

speaker', atu 'towards addressee (or a $3^{\text {rd }}$ person)', a 'elake 'upwards' and iho 'downwards', but these two local directionals are not speaker oriented, in contrast to Māori.

The examples below show the wide range of combinatorial possibilities between deictic directionals and motion verbs non-spatially oriented. Verbs such as sa'ele 'walk' and $k a k u$ 'arrive' are compatible with the three centripetal, centrifugal and transverse directionals:

\section{EAST FUTUNAN}

(78) Sa'ele mai!

walk CPTE

'Come here!' (Moyse-Faurie 1997:178)

(79) Sa'ele atu!

walk $\mathrm{CFG}$

'Go away!' (id.)

(80) Sa'ele ake!

walk TRANSV

'Walk!' (to someone who is not near the speaker) (id.)

(81) Kua kaku mai le folau.

PFV arrive CPTE SPC travellers

'The travellers arrived (here).' (Moyse-Faurie 1997:111)

(82) Kua kaku atu le folau.

PFV arrive CFG SPC travellers

'The travellers arrived (at your place).' (id.:112) 
(83)

Kua kaku ake le folau.

PFV arrive TRANSV SPC travellers

'The travellers arrived (over there).' (id.:113)

The same symmetric compatibility is found between directionals and perception or speech verbs:

$$
\begin{array}{lcccc}
E & \text { io } \quad \boldsymbol{m a i} & a & i a . \\
\text { NPST agree } & \text { CPTE } & \text { ABS } & \text { 3SG } \\
\text { 'He agrees } & \text { with me/us.' (id.:11) }
\end{array}
$$

$$
\begin{array}{llllll}
E & \text { kau } \text { io } \quad \text { atu } & e & t \bar{a} & \text { ano. } \\
\text { NPST } & 1 \mathrm{SG} \text { agree } & \mathrm{CFG} & \text { NPST } & \text { 1DU.INCL } & \text { go } \\
\text { 'I agree with you, we are going to leave.' (id.::112) }
\end{array}
$$

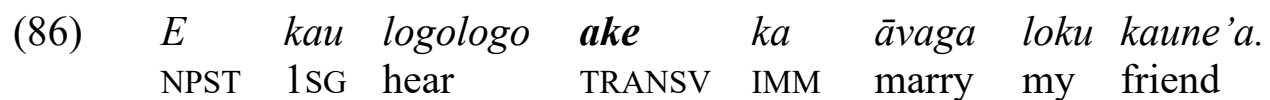

'I hear that my friend is getting married.' (id.:113)

In East Futunan, there are, however, incompatibilities between verbs such as 'au 'come' or ave 'take' and some of the directionals, due to semantic incompatibilities; consequently, there is an asymmetry in the combination of motion and manipulation verbs with directionals. For example, 'au 'come' cannot combine with the centrifugal directional $a t u$, but can be followed by the transverse directional ake:

$$
\begin{aligned}
& \text { 'Au ake mu'a ei loku tama! } \\
& \text { come TRANSV first eh! my son } \\
& \text { 'Do come there first, my son!' }
\end{aligned}
$$

On the other hand, the verb ave 'take' cannot combine with the centripetal directional mai.

\subsection{Other uses of directionals}

Although the majority of the occurrences of the directionals pertain to spatial reference, they are also found in several other functions:

(i) As benefactive participants (including addressees, as in (89)), they may occur instead of the explicit beneficiary participant, as in the examples below. 
(88) Na kakau mai le toe e lona tinana. PST send CPTE SPC child ERG his mother

'The mother sent me/us her child.' (Moyse-Faurie 1997:111)

(89) E kau kole atu ke ke 'au.

NPST 1SG ask CFG that 2SG come

'I am asking you to come.' (id.:112)

(90) Seu ake sana ne'akai!

serve TRANSV his food

'Serve him some food!' (id.:113)

(ii) They may convey aspectual or modal values. In East Uvean, for example, atu may

confer a continuous aspect value as in (91), whereas ake is oriented towards the future (92):

\section{EAST UVEAN}

(91) 'E lelei age ke ke 'alu o hoko atu tau akó $i$ Falani! NPST well TRANSV that 2SG go COMPcontinue CFG your study STAT France 'It would be good if you go and continue your studies in France!'

(92) I te 'aho aké ne'e matou olo o gelu. STAT SPC day UP PST 1PL.EXCL go(PL) COMP fish

'On the next day, we went fishing.' (Moyse-Faurie 2016:89)

(iii) All the directionals can occur in constructions expressing comparison of similitude or inequality (Moyse-Faurie 2018):

EAST FUTUNAN

E fetoso loku loto ke lasi ake au $i$ le 'uluaki.
NPST pull my will that big TRANSV $1 \mathrm{SG}$ OBL
'I want to be bigger than my elder (brother).'

\section{Combination of prepositions and directionals}

In the last part of this article, I will examine the uses and distribution of the Source and Goal prepositions on the one hand, and the deictic directional adverbs on the other hand, taking into account their combinatorial possibilities, the spatial meaning they convey, the position of the participants, and the verb meaning, in order to better understand the asymmetry between Goal and Source as far as the combination of prepositions and directionals is concerned. 


\subsection{Combination of the centripetal directional and the Source preposition}

The centripetal directional can combine with the Source preposition whether the two forms are phonologically similar (East Uvean) or not (East Futunan, Niuafo'ou, Marquesan). In East Futunan, as mentioned before, the Source preposition (SOURCE) is mei, which is different from the centripetal directional modifier mai 'towards the speaker'. In East Uvean, both morphemes are formally identical, but still differ in their syntactic and semantic functions, in the same way as mei and mai in East Futunan, as can be seen in the examples (94) and (95) in which they both occur.

\section{EAST FUTUNAN}

$\begin{array}{llllll}E & \text { ke } & \text { makape } & \text { mai } & \text { mei fale? } \\ \text { NPST } & 2 S G & \text { run } & \text { CPTE } & \text { SOURCE house }\end{array}$

'Are you going to run towards us from the house?'

E mapusi mai le matagi mei 'uta.

NPST blow CPTE SPC wind SOURCE inland

'Wind is blowing towards us from inland.'

In Niuafo'ou, both morphemes are also formally distinguished, the directional mai indicating the direction towards the deictic centre, and the preposition mei the Source/origin of the trade, as is shown in (96).

\section{NIUAFO'OU}

$$
\begin{aligned}
& \text { Ne au fakatau mai te peni mei kolo. } \\
& \text { PST 1SG trade CPTE SPC pen SOURCE town } \\
& \text { 'I bought a pen in town.' (Tsukamoto 1988:167) }
\end{aligned}
$$

In the East Uvean example (97), we find exactly the same meaning contrast between the directional and the preposition, in spite of their formal identity:

\section{EAST UVEAN}

$$
\begin{array}{llll}
\text { 'E hake mai (ia) mai } & \text { tai. } \\
\text { NPST go.up CPTE (3SG) SOURCE } & \text { sea } \\
\text { 'He is coming toward us from the sea.' }
\end{array}
$$




\subsection{Combination of the centripetal directional and the Goal or static/essive prepositions}

In East Futunan, the centripetal directional can combine with the Goal preposition (98) as well as with the static preposition and the Source preposition (99), each having different referents belonging to different phrases.

\section{EAST FUTUNAN}

E falele mai le niu ki loku fale. NPST lean CPTE SPC coconut GOAL my house 'The coconut tree is leaning towards my house.' (Moyse-Faurie 1997:111)

(99) E pale mai le ta'ine $\boldsymbol{i}$ le gā kākega mei le vai. NPST go.up CPTE SPC girl STAT SPC CLS ladder SOURCE SPC river 'The girl is coming up toward us on a small staircase, coming from the river.' (traj074-FUD)

In East Uvean, it is also possible to combine the centripetal deictic directional either with the Goal preposition (100) or with the static one (101), each phrase having different referents:

\section{EAST UVEAN}

(100) 'E au tu'ania na'a lua tuai mai ki te fonó. NPST 1SG fear fear.that 2DU be.late CPTE GOAL SPC meeting 'I fear that you will be late for the meeting. ' (Moyse-Faurie 2006:106)

(101) 'E lelei age ke ke ha'u apogipogi o tokoni mai NPST well CFG that 2SG come tomorrow COMP help CPTE $i$ te gāue'aga! STAT SPC field

'It will be good if you come to help me tomorrow in the fields.' (id.:240)

Quite frequent is the combination of the centripetal directional mai and the Goal preposition $k i$, if both have the same personal referent:

\section{EAST UVEAN}

(102) Tuku tau 'ita mai kiā au! stop your anger CPTE GOAL 1SG 'Stop being angry at me.'

(103) Foki mai kiā au! return CPTE GOAL 1SG 'Come back toward me!' 
The Samoan directional mai "indicating direction towards the speaker or some other chosen point of' (Mosel \& Hovdhaugen 1992:380) may combine with the static locative preposition $i$ (104) and such is also the case in Tuvaluan (105).

\section{SAMOAN}

...le teine lenei 'o tā'oto mai $\boldsymbol{i}$ le fuefue. ...SPC girl DEIC PROG lie CPTE STAT SPC fuefue

'...this girl who was lying in the fuefue [a plant].' (Mosel \& Hovdhaugen 1992:380)

TUVALUAN

(105) te fale tèlā $i$ mua mai $i$ te maneapa SPC house DEIC STAT front CPTE STAT SPC maneaba 'the house on this side of the maneaba' (Besnier 2000:347)

No asymmetry can be found between the three prepositions expressing Source, Goal and Place; they can equally combine with the centripetal directional.

\section{Other constructions linked to spatial expressions}

In this last descriptive section, I will rapidly mention three other constructions related to the expression of space, here again looking for asymmetry between Source and Goal.

\subsection{Constructions with the multifunctional conjunction/adverb mo}

We have seen that only one preposition is devoted to the expression of the Goal, whereas two locative prepositions can express the Source. In addition, another construction using the conjunction mo can also express the Source, even if its main meaning ('with, and, also') confers an additive or comitative value. Mo can express the Source in a comparison process between the position of the figure and the point of origin of the (most often fictive) motion, as in (106) and (107), the latter repeated from (63):

\section{EAST FUTUNAN}

(106) E tusa loku fale mo le tānuma. NPST to.face my house COM SPC cemetery 'My house is facing the cemetery.' (Moyse-Faurie 1997:87) 
$\begin{array}{llllllll}\text { (107) Nao mavae atu nei fua } & \text { a } & \text { Petelo mo } & \text { tãtou } \\ \text { IMM.PST leave CFG now just } & \text { ABS } & \text { Petelo } & \text { COM } & \text { 1PL.INCL } \\ \text { 'Petelo just left us.' (id.:95) } & & & & & \end{array}$

A similar function performed by mo is described in Tuvaluan by Besnier (2000:343) in the context of "verbs denoting motion or motion-like ideas away from the referent of the object":

TUVALUAN

(108) Tamaliki ne afuli nē au mo te lulu puaka. child PST chase ERG 1SG COM SPC pen pig 'I chased the children away from the pig pen.' (Besnier 2000:343)

\subsection{The faka- adverbial derivation}

Locative nouns (109) and toponyms (110) can be adverbialised with the prefix $\mathrm{faka}^{7}$, conferring the meaning 'in the direction of', 'in the vicinity of', in Bourdin's terms (1997:191). More precisely, this derivation confers a semantic specification of GoalApproximation. The derived adverb is part of the predicative verb phrase, immediately postposed to the verb.

\section{EAST UVEAN}

(109) 'E hake faka'uta ia Mikaele. NPST go up PREF.inland ABS Mikaele

'Mikaele is going up in the direction of the plantations.' (Moyse-Faurie 2016:169)

\section{EAST FUTUNAN}

\section{Na ano fakaSa'avaka māua. \\ PST go PREF.Sa'avaka 1DU.EXCL}

'We both went toward/in the direction of Sa'avaka.'

This Goal-Approximation derivation is only attested with centrifugal motion verbs, and hence cannot indicate a Place or Source approximation.

\footnotetext{
${ }^{7}$ Besides this locative 'approximative' adverbializing function, the prefix faka- derives adverbs of manner; its main function, however, is to derive bivalent or trivalent verbs from monovalent or bivalent ones, with a causative meaning.
} 


\subsection{Incorporation of local nouns}

Finally, a construction consisting of a verb of position or motion, immediately followed by a local noun or a noun referring to a place, is worth mentioning since it concerns only the expression of Goal or Place, and not that of Source. This construction is similar to what is known as object or noun incorporation, one of the well-known valency-reducing strategies, resulting in an intransitive verbal compound. When a noun referring to a place is incorporated to the verb, the resulting compound often confers a habitual meaning to the local or motion event.

In (111), fale 'house' is introduced by the stative/essive preposition $i$, indicating that the figure is right now staying at her place, and not elsewhere, while in (112), the verbal compound nofo fale indicates that the figure habitually stays at home:

(111) Kua nofo $\boldsymbol{i}$ fale a le tai'ine. PFV stay STAT house ABS SPC young.girl 'The young girl is now staying at home.'
Kua nofo fale a le tai'ine. PFV stay houseABS SPC young.girl 'The young girl is usually staying at home.'

\section{Conclusion}

We can conclude that in the Polynesian languages investigated in this article, the expression of Goal and Source is of similar complexity, though realised in different ways. Different types of asymmetry have been found. Goal is expressed by a single marker, $k i$, to which can be added some specification to indicate that the Goal has been reached, or to indicate the spatial relations on the absolute up/down axis with complex prepositions (cf. $\S 1.5 .2$ ). With regard to Source, different markers can be used, and this situation is remarkable in a typological perspective, as it is a case of configurational asymmetry between Goal and Source: the expression of Goal is more straightforward than the expression of Source.

It is thus not a question of complexity which distinguishes between the expression of the Source and the expression of the Goal, but a question of variety of resources offered to 
express fine-grained distinctions for Source vs. Goal depending on the position of the figure, which enables to detail different perspectives. In the case of the Source expression, if the figure is still at its point of departure, the static/essive preposition is used; in contrast, if the figure has already left its initial point, the source/ablative preposition is required.

Another case of asymmetry relates to the fact that there is only one Source oriented deictic directional, 'towards speaker', whereas there are two Goal oriented directionals, 'away from speaker and addressee' and 'towards addressee' (cf. §2.1). The Goal preposition also has more fine-grained possibilities for the encoding of Goal-Extent, due to its possible combination with verbs in order to form complex prepositions. These complex prepositions can take into account the position of the figure which will reach the Goal. Source has a richer choice as far as locative prepositions are concerned, but it has no complex verbal prepositions except for the temporal 'since' meaning (cf. §1.5.2). Contrasting with the GoalApproximation strategy expressed with the faka-derivation, no equivalent construction has been found for the Source. As stated by Kopecka \& Ishibashi (2011:147), asymmetry between Source and Goal expressions is not unilateral, and must be studied taking into consideration each component and construction involved in the expression of Goal, Source and Place in a given language.

Abbreviations (others than the Leipzig glossing rules conventions) ABS absolutive marker, ANAPH anaphoric, CFG centrifugal directional, CPTE centripetal directional, COLL collective, COM comitative, COMP complementiser, DEIC deictic, DIR directional, DU dual, EMPH emphatic particle, ERG ergative marker, EXCL exclusive, GOAL allative preposition, HUM human, IMM immediate, INC inceptive, INCL inclusive, INT intensifier, NPST non past, NSPC non specific article, PFV perfective, PRED predicative marker, PREF prefix, PROG progressive, PST past, RESTR restrictive particle, SOURCE ablative 
preposition, SPC specific article, STAT static/essive preposition, SUCC successive, TRANSV

transverse directional.

\section{Références}

Bauer, Winifred. 1997. The Reed Reference grammar of Māori, Reed Books.

Besnier, Niko. 2000. Tuvaluan. A Polynesian Language of the Central Pacific, London/New York: Routledge.

Bourdin, Philippe. 1997. On Goal-bias across languages: modal, configurational and orientational parameters. In Bohumil Palek (ed.), Proceedings of LP'96, Charles University Press. 185-218.

Cablitz, Gabriele H. 2006. Marquesan: A Grammar of Space, Trends in Linguistics, Studies and Monographs 169, Berlin and New York: Mouton de Gruyter.

Creissels, Denis. 2006. Encoding the distinction between location, source and destination: A typological study. In Hickmann, Maya and Stéphane Robert (eds.), Space in languages. Linguistic Systems and Cognitive Categories, John Benjamins Publishing Company, Typological Studies in Language 66. 19-28.

Du Feu, Veronica. 1996. Rapanui, London/New York: Routledge.

François, Alexandre. 2003. Of men, Hills, and Winds: Space directionals in Mwotlap, Oceanic Linguistics 42-2. 408-436.

Greenhill S.J. and Clark R. 2011. Pollex-Online: The Polynesian Lexicon Project Online. Oceanic Linguistics, 50(2). 551-559, (http://pollex.org.nz/).

Henquel, Joseph R.P. 1910. Talanoa ki 'Uvea nei. Histoires de Wallis. [Traduit, annoté et présenté par Daniel Frimigacci et Siolesio Pilioko (unpublished manuscript)].

Hooper Robin. 2004. Perception verbs, directional metaphor and point of view in Tokelauan discourse, Journal of Pragmatics 36. 1741-1760.

Ishibashi, Miyuki, Anetta Kopecka \& Marine Vuillermet. 2006. Matériel visuel pour élicitation des données linguistiques. Laboratoire Dynamique du Langage, CNRS/Université Lyon 2. Projet de Fédération de recherche en Typologie et Universaux Linguistiques http://tulquest.huma-num.fr/fr/node/132)

Kopecka, Anetta and Miyuki Ishibashi. 2011. L'(a)symétrie dans l'expression de la Source et du But : perspective translinguistique, Les Cahiers de Faits de Langues, 3. 131-149.

Lichtenberk, Frantisek. 2003. Directionality and displaced directionality in Toqabaqita. In: E. Shay and U. Seibert (eds.), Motion, Direction and Location in languages. In honor of Zygmunt Frajzyngier. Amsterdam/Philadelphia, John Benjamins Publishing Company, Typological Studies in Language 56.

Mayer, Raymond. 1976. Les transformations de la tradition narrative à l'île Wallis (Uvea), Paris, Musée de l'Homme, Publications de la Société des Océanistes 38.

Mosel, Ulrike and Even Hovdhaugen. 1992. Samoan Reference Grammar. The Institute for Comparative Research in Human Culture, Scandinavian University Press.

Moyse-Faurie, Claire. 1995. Le xârâcùù, langue de Thio-Canala (Nouvelle-Calédonie). Éléments de syntaxe, Peeters-Selaf (Langues et Cultures du Pacifique 10).

- 1997. Grammaire du futunien, Nouméa, Centre de Documentation Pédagogique, coll. Université.

— 2010. (Dé)Grammaticalisation d'expressions spatiales dans des langues océaniennes. In Typologie et Comparatisme. Hommages offerts à Alain Lemaréchal. Textes réunis par Injoo Choi-Jonin, Marc Duval et Olivier Soutet, Leuven: Peeters, Orbis/Supplementa, t. 28. 295-314.

- 2016. Te lea faka 'uvea - Le wallisien (Les langues du Monde 7). Paris: Peeters. 
- 2019. Similarity, comparison of equality and verbal manner demonstratives in Polynesian languages, Faits de Langues 50(1):135-156. https://doi.org/10.1163/1958951405001011

Nikitina, Tatiana. 2009. Subcategorization pattern and lexical meaning of motion verbs: a study of the source/goal ambiguity, Linguistics 47(5)5. 1113-1141. http://doi.org/10.1515/LING2009.039

Ozanne-Rivierre Françoise. 1997. Spatial references in New Caledonian languages, in G. Senft (ed.), Referring to Space. Studies in Austronesian and Papuan Languages. Oxford: Clarendon Press, Oxford Studies in Anthropological Linguistics. http://doi.org/10.1075/hcp.3.08oza

- 1998. Spatial Orientation in some Austronesian Languages. In Catherine Fuchs et Stéphane Robert (eds.), Language Diversity and Cognitive Representations, Amsterdam/Philadelphia, John Benjamins Publishing Company. 73-84.

Pawley, Andrew. 1973. Some problems in proto-Oceanic grammar, Oceanic Linguistics 12. 102-188. http://doi.org/10.2307/3622854

- 2003. Grammatical Categories and Grammaticisation in the Oceanic Verb Complex. In A. Riehl and T. Savella (eds.), Cornell Working Papers in Linguistics 19. 149-172.

Ross, Malcolm. 2004. The grammaticization of directional verbs in Oceanic languages. In I. Bril and F. Ozanne-Rivierre (eds.), Complex Predicates in Oceanic Languages. Studies in the Dynamics of Binding and Boundness. Berlin, Walter de Gruyter. http://doi.org/10.1515/9783110913286.297

Stolz, Thomas, Sander Lestrade and Christel Stolz. 2014. The Crosslinguistics of ZeroMarking of Spatial Relations. De Gruyter, Studia Typologica 15. http://doi.org/10.1524/9783050065304

Talmy, Leonard. 2017. Foreword. Past, present, and future of motion research. In I. IbarretxeAntuñano (ed.), Motion and Space across Languages, John Benjamins Publishing Company. 1-12. http://doi.org/10.1075/hcp.59.01tal

Tsukamoto, Akihisa. 1988. The language of Niuafo'ou Island, $\mathrm{PhD}$, Canberra, Australian National University. 